Jurnal Tanah dan Sumberdaya Lahan Vol 8 No 1: 179-188, 2021

e-ISSN:2549-9793, doi: 10.21776/ub.jts1.2021.008.1.21

\title{
TRANSFORMASI KARAKTERISTIK TANAH SAWAH PADA LAHAN BEKAS PENAMBANGAN EMAS DI KABUPATEN SIJUNJUNG SUMATERA BARAT
}

\section{Transformation of Paddy Soil Characteristics at Ex-Gold Mining Land in Sijunjung Regency, West Sumatera}

\author{
Elsa Lolita Putri*, Gusmini, Adrinal, Yaherwandi \\ Program Studi Ilmu Tanah, Fakultas Pertanian, Universitas Andalas, Padang Sumatera Barat 25163 \\ *Penulis korespodensi: elsalolitaputri@gmail.com
}

\begin{abstract}
The process of physical and chemical properties of the former gold mining soil which is caused by the transformation of different land conditions in natural rice fields, reclaimed rice fields, and mine fields. This study aims to determine the differences in the characteristics of the former gold mining soil in natural rice fields, reclaimed rice fields and mining fields in Sijunjung Regency. There were three sampling locations with three sample points each and the samples were analyzed physically and chemically. Results of this study showed that natural paddy soil has optimal conditions for the growth of rice plants followed by reclaimed lowland soil and the worst was in mining paddy soil based on soil physical and chemical properties. The difference in soil physical properties in the form of natural paddy soil texture was smoother compared to land conditions in reclaimed rice fields and mining rice fields. This was due to intensive inundation processes, which created a plough tread layer, low volume weight accompanied by a moderate total pore space. The difference in chemical properties was in the stable $\mathrm{pH}$ of natural paddy soil due to inundation and high organic carbon accompanied by rice reclamation and very low organic carbon in mining soils, which would affect the growth of rice plant.
\end{abstract}

Keywords: mining fields, natural rice fields, reclaimed rice fields, soil chemistry, soil physics

\section{Pendahuluan}

Kabupaten Sijunjung, Provinsi Sumatera Barat memiliki potensi sumberdaya alam berupa produksi pertanian serta mengandung berbagai sumberdaya mineral (bahan tambang) seperti batu bara, emas, biji besi, batu gamping/kapur, dolomit, batu marmer, dan batu granit (Anderson, 2018). Industri pertambangan merupakan salah satu industri yang diandalkan pemerintah Indonesia untuk mendatangkan devisa. Selain itu, petambangan juga menyediakan lapangan kerja serta sumber Pendapatan Asli Daerah bagi kabupaten/kota. Kegiatan pertambangan tersebut meliputi: eksplorasi, eksploitasi, pengolahan/ pemurnian, pengangkutan mineral/bahan tambang. Sumberdaya mineral yang berupa endapan bahan galian memiliki sifat khusus dibandingkan dengan sumberdaya lain yaitu wasting assets atau diusahakan ditambang, maka bahan galian tersebut tidak akan "tumbuh" atau diperbarui kembali (unrenewable resources).

Kenagarian Padang Sibusuk di Kecamatan Kupitan Kabupaten Sijunjung, Sumatera Barat merupakan salah satu nagari yang memiliki kandungan emas yang tinggi namun berada pada kawasan budidaya khususnya padi sawah. Kegiatan penambangan emas di kawasan budidaya ini mengakibatkan gangguan terhadap produksi tanah terutama budidaya pertanian. Aktivitas penambangan emas tersebut dapat berdampak pada kondisi lingkungan baik secara fisik, kimia, dan biologi. Secara fisik dapat dilihat dari terbukanya lahan yang cukup luas menjadi lahan tandus berwujud padang pasir berisi tailing. Secara kimiawi menyebabkan 


\section{Jurnal Tanah dan Sumberdaya Lahan Vol 8 No 1: 179-188, 2021 e-ISSN:2549-9793, doi: 10.21776/ub.jts1.2021.008.1.21}

pencemaran air, tanah, dan vegetasi akibat dari penggunaan zat yang berbahaya. Secara biologi dapat dilihat dari hilangnya vegetasi dan asosiasi organisme. Hal lain yang menjadi sorotan dari perusakan lahan akibat penambangan emas ini adalah adanya Penambang Emas Tanpa Izin (PETI) yang selain merusak lingkungan juga membahayakan jiwa penambang karena keterbatasan pengetahuan penambang dan juga tidak adanya pengawasan dari dinas instansi terkait(Yudhistira et al., 2012). Aktivitas PETI maupun perusahaan tambang emas besar lainnya menjadi salah satu penyebab degradasi lingkungan di daerah bekas tambang, mulai dari rusaknya bentang lahan, lenyapnya vegetasi permukaan, meningkatnya erosi, banjir dan kekeringan, serta kerusakan lingkungan lainnya.

Berdasarkan dari asalnya, emas dapat dibagi menjadi dua yaitu emas primer dan emas sekunder. Emas primer adalah emas yang keberadaanya bersamaan mineral logam lainnya, seringkali dicirikan dengan adanya sejumlah urat-urat kuarsa dan secara keseluruhan semua itu terbentuk sebagai hasil akhir dari aktivitas vulkanik. Emas sekunder adalah emas yang pada umumnya terdapat pada dataran sungai baik yang purba maupun yang masa kini (recent), emas ini biasanya berasal dari hasil transportasi melalui akar (Ahyani, 2011). Salah satu contoh dari emas sekunder ini atau juga dikenal sebagai emas latakan/ placer gold adalah emas yang ditemukan di Nagari Padang Sibusuak, Kabupaten Sijunjung Sumatra Barat. Emas sekunder yang berada pada dataran sungai juga berdampak pada lokasi sawah yang berada disekitar aliran irigasi dan sungai dalam upaya memudahkan ketersediaan air pada saat proses penanaman padi sawah. Sawah mengalami dampak besar dalam perusakan lahan akibat penambangan emas ini

Nasi yang berasal dari padi merupakan makanan pokok terbesar dikonsumsi secara global di 112 negara di dunia namun padi menjadi makanan pokok utama di banyak negara yang berpenghasilan rendah dan menengah sehingga penting untuk ketahanan pangan dan kemiskinan (Chivenge et al., 2020). Pertambangan emas yang terjadi di Nagari Padang Sibusuk Kabupaten Sijunjung ini banyak mengorbankan lahan pertanian khususnya tanah sawah masyarakat lokal. Hal ini menyebabkan luasan sawah produktif di
Kabupaten Sijunjung khususnya pada Nagari Padang Sibusuk mengalami penurunan akibat alih fungsi lahan tersebut. Data (BPS, 2020) menunjukkan bahwa dari tahun 2018 hingga 2019 terjadi penurunan luas lahan sawah produktif yang ada di Provinsi Sumatera Barat sebesar -1.380 ha.

Dari hasil wawancara dengan masyarakat di Jorong Ladang Kapeh Nagari Padang Sibusuk Kabupaten Sijunjung diperoleh informasi bahwa penambangan emas pada lahan sawah produktif sudah berlangsung sejak tahun 2004, namun berhenti pada tahun 2016. Setelah terhentinya kegiatan PETI tersebut (2016-sekarang) tanah bekas tambang emas ada yang ditinggalkan serta sebagian direklamasi secara sederhana oleh masyarakat dengan cara menimbun kembali sawah dengan tanah dari daerah lain sehingga permukaan tanah bekas tambang yang dipenuhi tailing dapat tertutupi oleh tanah timbunan serta penggenangan sawah dapat dilakukan kembali. Walaupun sudah dilakukan reklamasi secara tradisional, namun produksi padi sawah di lokasi ini hanya sekitar $50 \%$ dibandingan dengan produksi sebelum kegiatan penambangan emas. Rendahnya produktivitas lahan bekas tambang emas ini mengakibatkan sedikitnya masyarakat yang tertarik untuk mereklamasi kembali tanah sawah sehingga banyak sawah yang masih terlantar dan tidak bisa digunakan lagi untuk budidaya pertanian.

Sawah di Nagari Padang Sibusuk Kabupaten Sijunjung Sumatera Barat memiliki tiga bentuk transformasi tanah akibat dari kegiatan pertambangan emas tersebut dapat dilihat pada Gambar 1. diantaranya adalah sawah bekas tambang emas tanpa reklamasi, sawah bekas tambang emas telah direklamasi tradisional serta sawah alami yang tidak mengalami penambangan emas. Kajian karakteristik tanah sawah dibutuhkan dalam transformasi perubahan tanah sawah pada bekas penambangan emas ini untuk mengetahui permasalahan dan teknologi yang tepat untuk memperbaiki tanah tersebut secara optimal.

\section{Bahan dan Metode}

Penelitian ini telah dilaksanakan pada bulan Juli hingga Oktober 2020 pada tanah bekas penambangan emas di Jorong Ladang Kapeh 
Nagari Padang Sibusuk Kabupaten Sinjung, Sumatera Barat. Analisis tanah dilakukan di Laboratorium Fisika dan Kimia Jurusan Tanah Fakultas Pertanian Universitas Andalas. Prosedur pelaksanaan penelitian ini dibagi menjadi empat tahap, yaitu tahap persiapan, survei pendahuluan, survei utama, dan analisis di laboratorium. Penelitian dimulai dengan tahap persiapan pengumpulan data sekunder berupa peta administrasi, peta penggunaan lahan, dan peta titik sampel dan dilanjutkan dengan kajian pustaka untuk mendapatkan gambaran umum tentang kegiatan penelitian yang akan dilakukan, wilayah penelitian, dan informasi-informasi tambahan yang dibutuhkan dalam penelitian. Survei pendahuluan merupakan kegiatan yang terdiri atas a) peninjauan daerah penelitian untuk mendapatkan gambaran tentang kondisi lapangan, b) cara kerja di lapangan, c) menentukan lokasi pengamatan tanah serta pengambilan sampel tanah yang dilakukan untuk menenrukan posisi geografis titik sampel yang diambil di lapangan dan juga untuk mencocokan titik yang ditetapkan pada peta dengan kondisi sebenarnya di lapangan. Survei utama teridiri dari pengamatan di lapangan sesuai tiitk sampel yang ditetapkan dan koreksi pada survei pendahuluan yang dapat dilihat pada peta titik sampel pada Gambar 2 serta dilanjutkan dengan pengambilan sampel tanah secara random sampling (Kurnia et al., 2006) dengan dua macam sampel tanah yaitu sampel tanah terganggu dan utuh. Tahap ke empat adalah analisis tanah di laboratorium yang diambil pada masing-masing titik dengan parameter dan matoda analisis sesuai dengan juknis analisis tanah (BPT, 2009). Parameter dan metode analisis tanah dapat dilihat pada Tabel 1.
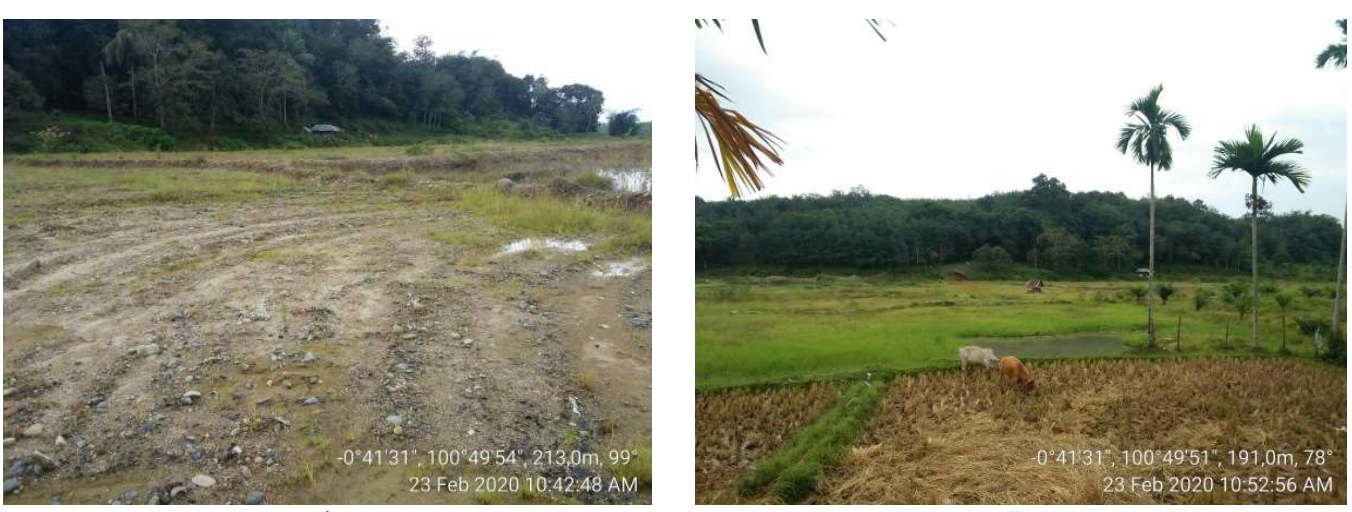

A

B

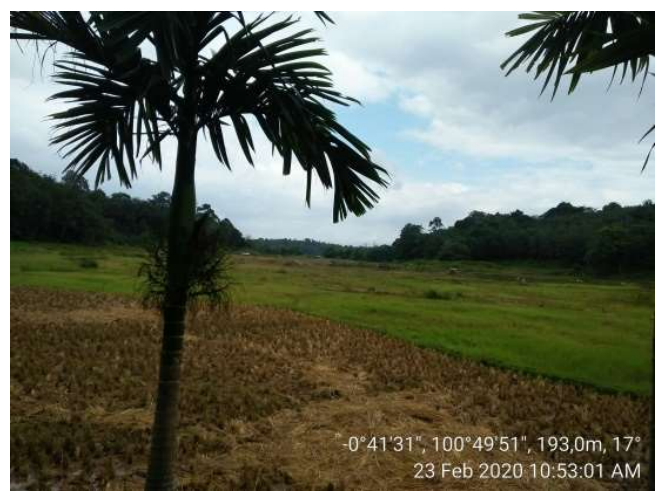

C

Gambar 1. Bentuk tutupan lahan sawah di Nagari Padang Sibusuk Kabupaten Sijunjung yaitu (a) sawah bekas tambang emas tanpa reklamasi (b) sawah bekas tambang emas telah direklamasi tradisional (c) sawah alami yang tidak mengalami penambangan emas. 


\section{Jurnal Tanah dan Sumberdaya Lahan Vol 8 No 1: 179-188, 2021 e-ISSN:2549-9793, doi: 10.21776/ub.jts1.2021.008.1.21}
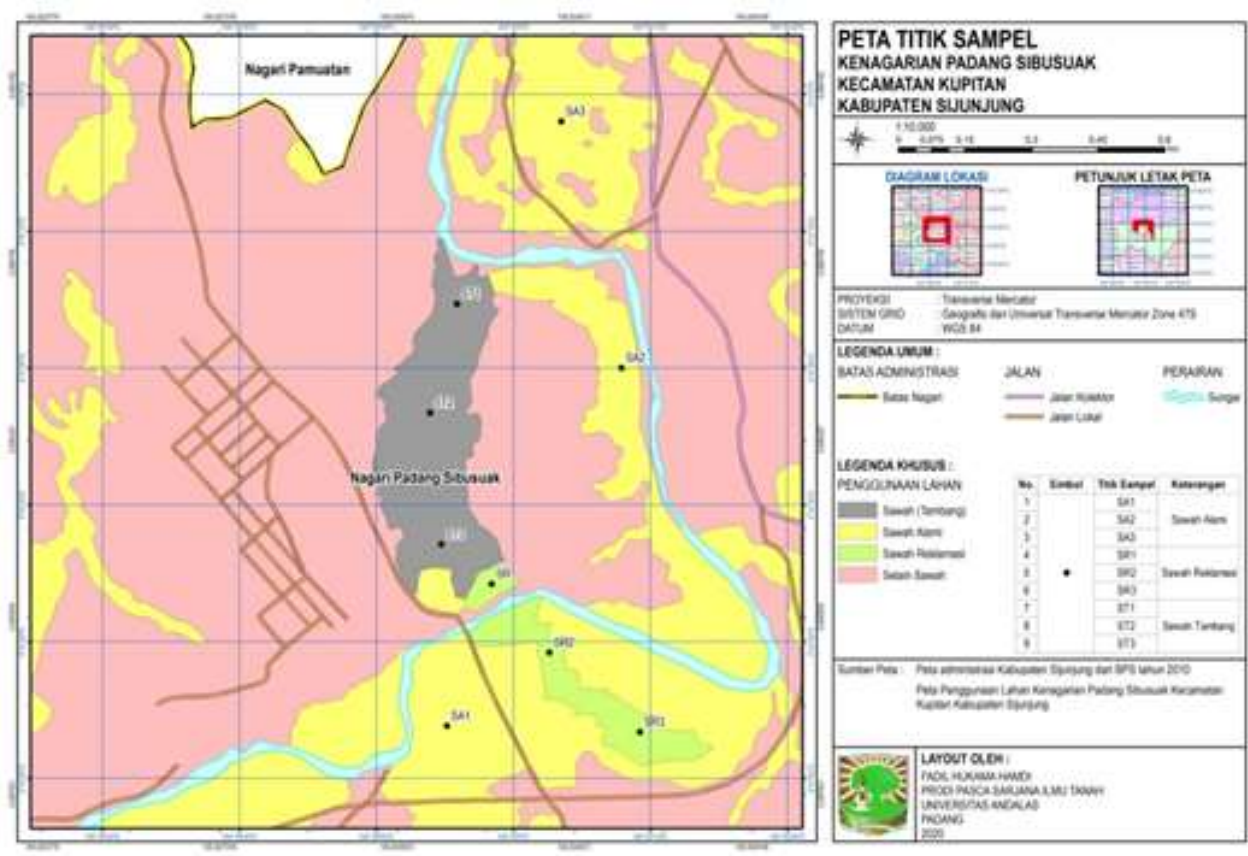

Gambar 2. Peta titik sampel.

Tabel 1. Parameter dan metode analisis tanah.

\begin{tabular}{clccc}
\hline No & \multicolumn{1}{c}{ Parameter } & Satuan & Metode Analisis & Sampel \\
\hline 1 & Sifat Fisika & & & \\
& Tekstur & - & Ayakan \& pipet & Komposit \\
& Bobot volume tanah & $\mathrm{g} \mathrm{cm}^{-3}$ & Bongkah alami & Utuh \\
& Total ruang pori & $\%$ & Pendekatan BV dan BJ & Utuh \\
\hline 2 & Sifat Kimia & & & \\
& pH tanah $\left(\mathrm{pH} \mathrm{H}_{2} \mathrm{O}\right)$ & - & Potensiometrik & Komposit \\
& C-organik & $\%$ & Walkley-Black & Komposit \\
\hline
\end{tabular}

\section{Hasil dan Pembahasan}

\section{Sifat fisika tanah}

\section{Tekstur}

Tekstur tanah sangat berperan dalam proses pembentukan tanah sawah yang baik untuk pertumbuhan tanaman padi. Tiga jenis transformasi kondisi tanah sawah bekas penambangan emas di daerah Sijunjung disajikan pada Tabel 2. Tekstur tanah dari ketiga kondisi tanah sawah bekas pertambangan emas ini menunjukkan keragaman akibat dari proses yang mempengaruhinya. Komposisi mineral liat dan tekstur tanah sangat berperan dalam pembentukan lapisan tapak bajak. Lapisan tapak bajak merupakan lapisan tipis pada sawah yang terbentuk oleh proses-proses pengolahan tanah, baik secara mekanik maupun manual dan bukan merupakan horizon genetik tersendiri (Hardjowigeno, 2007). Lapisan tapak bajak sangat berperan terhadap ketersediaan air dan pertumbuhan tanaman padi. Tanah sawah yang berlempung halus adalah tanah sawah yang paling optimal untuk pembentukan lapisan tapak bajak, dan tanah sawah dengan kandungan liat tinggi kurang nyata membentuk lapisan tapak bajak (BPPP, 2004). Kandungan liat yang tinggi pada tanah sawah alami 


\section{Jurnal Tanah dan Sumberdaya Lahan Vol 8 No 1: 179-188, 2021 e-ISSN:2549-9793, doi: 10.21776/ub.jts1.2021.008.1.21}

menandakan telah terjadinya intensifikasi penggunaan sawah pada tanah ini serta reklamasi yang telah dilakukan masyarakat dengan cara menimbun tanah bekas penambangan emas dengan liat menunjukkan perubahan yang besar bagi tekstur tanah dibandingkan tanah sawah tambang yang bertekstur pasir berlempung. Tanah sawah biasanya bertekstur tanah yang padat dengan adanya tanda-tanda genangan air permanen atau intermitten seperti pemisahan besi dan mangan pada matriks tanah (Krik, 2004).

Tabel 2. Tekstur tanah.

\begin{tabular}{|c|c|c|c|c|c|c|c|c|}
\hline \multirow[t]{2}{*}{ Label } & Pasir & Debu & Liat & Jumlah & Pasir & Debu & Liat & \multirow[t]{2}{*}{ Kelas Tekstur } \\
\hline & \multicolumn{4}{|c|}{ Fraksi (g) } & \multicolumn{3}{|c|}{$(\%)$} & \\
\hline $\mathrm{SA}$ & 0,96 & 0,06 & 0,18 & 1,2 & 14,28 & 22,31 & 63,41 & Liat \\
\hline SR & 3,46 & 0,04 & 0,08 & 3,58 & 55,60 & 16,07 & 28,32 & $\begin{array}{l}\text { Lempung liat } \\
\text { berpasir }\end{array}$ \\
\hline ST & 6,10 & 0,04 & 0,04 & 6,18 & 77,58 & 12,72 & 9,70 & Pasir berlempung \\
\hline
\end{tabular}

Keterangan: $\mathrm{SA}=$ Sawah Alami, $\mathrm{SR}=$ Sawah Reklamasi, $\mathrm{ST}=$ Sawah Tambang.

Ketebalan tapak bajak meningkat seiring dengan waktu budidaya dan cara pemadatan baik oleh manusia, hewan, maupun traktor saat pembajakan (Janssen dan Lennartz, 2007). Pada lapisan permukaan yang dicirikan oleh tekstur kasar pada tanah sawah reklamasi dan sawah tambang, pembentukan lapisan tapak bajak membutuhkan waktu 3 hingga 200 tahun, tergantung jenis tanah, iklim, hidrologi dan frekuensi genangan (Witt, 2005). Proses pematanngan lapisan tapak bajak mencapai hasil yang memuaskan pada 10 - 20 tahun dengan proses pembajakan dan pemadatan tanah (Liu et al., 2005). Dampak negatif dari konversi lahan pertanian dapat dikurangi dengan memperpanjang waktu genangan selama periode awal penanaman padi karena genangan mempercepat pembentukan tapak bajak yang dipadatkan dan secara substansial menurunkan laju infiltrasi (Kukal dan Sidhu, 2004).

\section{Bobot volume}

Bobot volume tanah di tiga lokasi penelitian menunjukkan nilai yang beragam (Gambar 3 . Kondisi tanah menunjukkan kandungan air yang banyak dan bobot volume rendah. Pada sawah alami yang memiliki bobot volume yang rendah menandakan tidak terbentuknya lapisan tapak bajak karena keberadaan air yang relatif dangkal dan akan menghambat proses pemadatan tanah (Rahayu et al., 2014). Bobot volume tanah sawah dipengaruhi oleh pengolahan dan sejarah penggunaan lahan (Yi et al., 2020). Tanah sawah alami yang mengalami penggenangan memiliki bobot volume yang rendah dibandingkan bobot volume tanah sawah reklamasi dan sawah tambang karena sawah alami yang sering mengalami genangan di lapangan menyebabkan kondisi anoksik tanah dan mengurangi laju dekomposisi bahan organik (Huang et al., 2015). Proses genangan dan homogenisasi sebelum terbentuk tanah sawah mengurangi kerapatan permukaan tanah dan dalam sebuah studi menunjukkan bahwa tanah sawah memiliki nilai bobot volume antara 0,98 - 1,24 $\mathrm{g} \mathrm{cm}^{-3}$ (Kölbl et al., 2014).

\section{Total ruang pori}

Total ruang pori pada ketiga jenis kondisi tanah sawah pada penilitian ini memiliki nilai beragam (Gambar 4). Kenaikan bobot volume tanah sawah tertinggi terjadi pada tanah tambang akibat proses penambangan yang menggunakan alat berat serta proses eksploitasi yang menghasilkan tailing berisi dominan pasir. Kenaikan bobot volume ini mengakibatkan penurunan total ruang pori tanah dan ukuran pori tanah (Hu et al., 2018). Kadar liat tanah yang lebih tinggi di kedalaman tanah menunjukkan ukuran pori yang lebih kecil, yang mengakibatkan semakin rendahnya pori makro di dalam tanah sehingga total ruang pori akan lebih besar. Sebaliknya partikel tanah yang lebih kasar di kedalaman tanah menyebabkan ukuran pori tanah menjadi lebih besar sehingga total ruang pori akan semakin kecil. Pengaruh tekstur terhadap identifikasi porositas tanah sawah memiliki fungsi untuk memperkirakan kandungan pasir, kandungan tanah liat dan sifat tanah lainnya (Qiao et al., 2018). 
Jurnal Tanah dan Sumberdaya Lahan Vol 8 No 1: 179-188, 2021

e-ISSN:2549-9793, doi: 10.21776/ub.jts1.2021.008.1.21

\section{$\mathrm{BV}\left(\mathrm{g} \mathrm{cm}^{-3}\right)$}

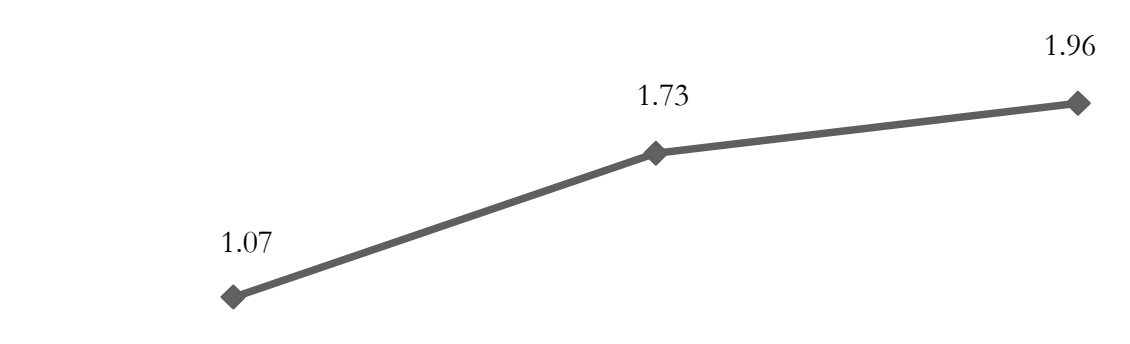

\begin{tabular}{ll}
\hline Sawah alami & Sawah reklamasi
\end{tabular}

Gambar 3. Diagram bobot volume tanah.

\section{TRP (\%)}

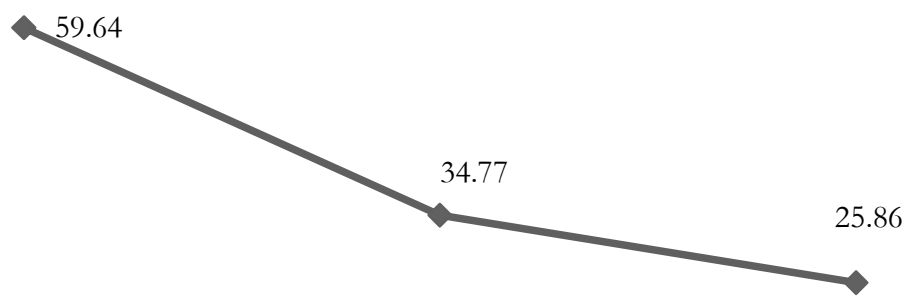

Sawah alami

Sawah reklamasi

Sawah tambang

Gambar 4. Total ruang pori (TRP) tanah.

\section{Sifat kimia tanah}

pH tanah

Kemasaman tanah $(\mathrm{pH})$ pada semua kondisi tanah sawah yaitu sawah alami, sawah reklamasi dan sawah tambang di kedua jenis $\mathrm{pH} \mathrm{H}_{2} \mathrm{O}$ dan $\mathrm{pH} \mathrm{KCl} \mathrm{memiliki} \mathrm{kriteria} \mathrm{masam} \mathrm{hingga} \mathrm{netral}$ yaitu bekisar antara 4,09-6,15 (Gambar 5). Hal ini menunjukkan bahwa tanah sawah alami memiliki $\mathrm{pH}$ tanah yang lebih netral dibandingkan dengan tanah bekas tambang yang telah mengalami reklamasi maupun tanah sawah tambang yang belum direklamasi. Tanah sawah yang mengalami proses penggenangan akan berpengaruh pada tanah-tanah masam dan alkalis yang menyebabkan semua $\mathrm{pH}$ tanah mendekati netral yaitu 6,0 - 7,0 kecuali pada tanah gambut masam atau tanah dengan kada $\mathrm{Fe}$ aktif $\left(\mathrm{Fe}^{2+}\right)$ yang rendah (Hardjowigeno dan Rayes, 2005). 


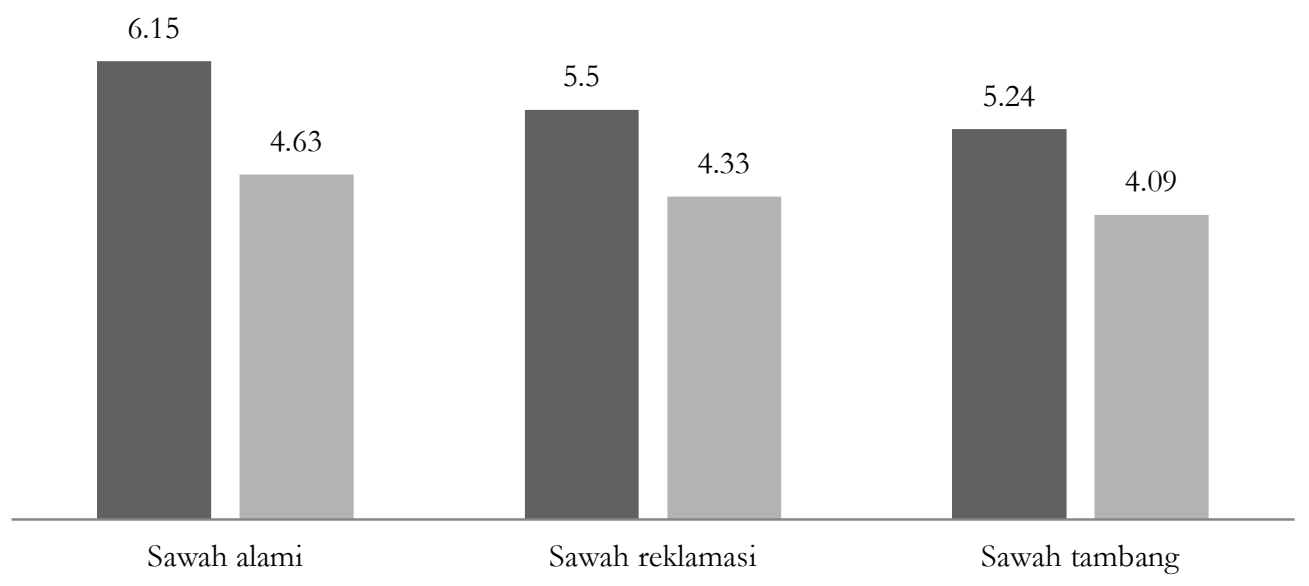

Gambar 5. pH tanah.

Perubahan elektrokimia pada tanah sawah menyebabkan peningkatan $\mathrm{pH}$ di sebagian besar tanah masam sedangkan penurunan $\mathrm{pH}$ saat tanah berkapur dan sodik digenangi disebabkan oleh akumulasi karbon dioksida (Witt, 2005). Perendaman tanah di ekosistem persawahan mengubah kondisi reduksioksidasi, berdampak pada siklus hara dan mendukung flora dan fauna. Pada biasanya menerima pupuk dan pestisida yang akan dipengaruhi oleh sinar matahari, suhu, $\mathrm{pH}$ tanah dan kondisi redoks, serta kosentrasi oksigen dalam air. Tinggi $\mathrm{pH}$ tanah dan air serta suhu memicu penguapan amonia saat aplikasi pupuk nitrogen. Demikian pula senyawa residu yang berbeda dapat dihasilkan dari pestisida yang digunakan. Pada tanah sawah reklamasi dan tambang juga memiliki pengaruh dalam perubahan $\mathrm{pH}$ akibat proses penambangan emas sebelumnya. Kegiatan pengelolaan rutin dalam sistem padi mempengaruhi spesies kimia yang dilepaskan ke atsmosfer dan badan air. Oleh karena itu, layanan pengaturan menjadi penting karena ekosistem padi bekontribusi secara signifikan dalam menyeimbangkan aliran air, energi, dan nutrisi dalam tanah sawah (Burkhard et al., 2015).

\section{Karbon organik}

Kandungan karbon organik pada lokasi penelitian di ketiga jenis sawah yaitu sawah alami, sawah reklamasi dan sawah tambang memiliki kriteria sedang hingga rendah dengan nilai 2,02\% - 0,17\% (Gambar 6). Tanah sawah alami memiliki nilai karbon organik yang tinggi diikuti oleh tanah sawah reklamasi dan kandungan karbon organik terendah pada sawah tambang. Tanah sawah memiliki karbon organik dengan kriteria sedang karena adanya penambahan bahan organik yang berasal dari sisa-sisa akar tanaman padi serta berlangsungnya proses dekomposisi yang lebih lambat. Tanah reklamasi dengan kriteria karbon organik yang rendah karena mengalami input bahan organik yang masih muda dibandingkan sawah alami dan sawah tambang yang tidak memperoleh bahan organik setelah terjadi proses penambangan. (Arabia, 2009) menyatakan dalam hasil penelitiannya bahwa pada tanah sawah toposekuen berbahan induk vulkanik di daerah Bogor-Jakarta menandakan bahwa semakin sering tanah tergenang oleh penyawahan cenderung mengawetkan bahan organik karena dekomposisi bahan organik dalam suasana reduktif berlangsung lambat (terhambat).

Kandungan karbon organik tanah pada tanah kering seperti tanah sawah reklamasi dan sawah tambang dengan tanah yang disawahkan umumnya mempunyai pola yang sama, yaitu bahan organiknya semakin menurun seiring dengan bertambahnya kedalaman tanah. Hal ini 


\section{Jurnal Tanah dan Sumberdaya Lahan Vol 8 No 1: 179-188, 2021 \\ e-ISSN:2549-9793, doi: 10.21776/ub.jts1.2021.008.1.21}

disebabkan karena proses dekomposisi bahan organik oleh mikroorganisme yang hanya berlangsung di lapisan atas (Rahayu et al., 2014). Kandungan karbon organik yang tinggi pada tanah sawah dibandingkan dengan sawah reklamasi dan sawah tambang karena kandungan karbon organik tanah pada kedalaman $0-10 \mathrm{~cm}$ naik ketingkat tinggi dan stabil setelah 30 tahun penanaman padi (Liu et al., 2005). Tingkat akumulasi karbon orgaik yang lebih tinggi dikaitkan dengan penerapan luas pengembalian jerami padi ke lahan sawah yang menyebabkan lebih banyak input sisa padi dan mempercepat akumulasi karbon organik tanah (Jin et al., 2020). Selain peningkatan karbon organik tanah di lapisan tanah atas, kandungan bahan organik lebih tinggi di lapisan tanah bawah juga diamati lebih umum dikaitkan dengan pergerakan ke bawah sejumlah bahan organik terlarut dalam air dan karbon organik yang teradsorpsi ke partikel tanah liat (Fuhrmann et al., 2019).

- C-organik (\%) — Bahan organik (\%)

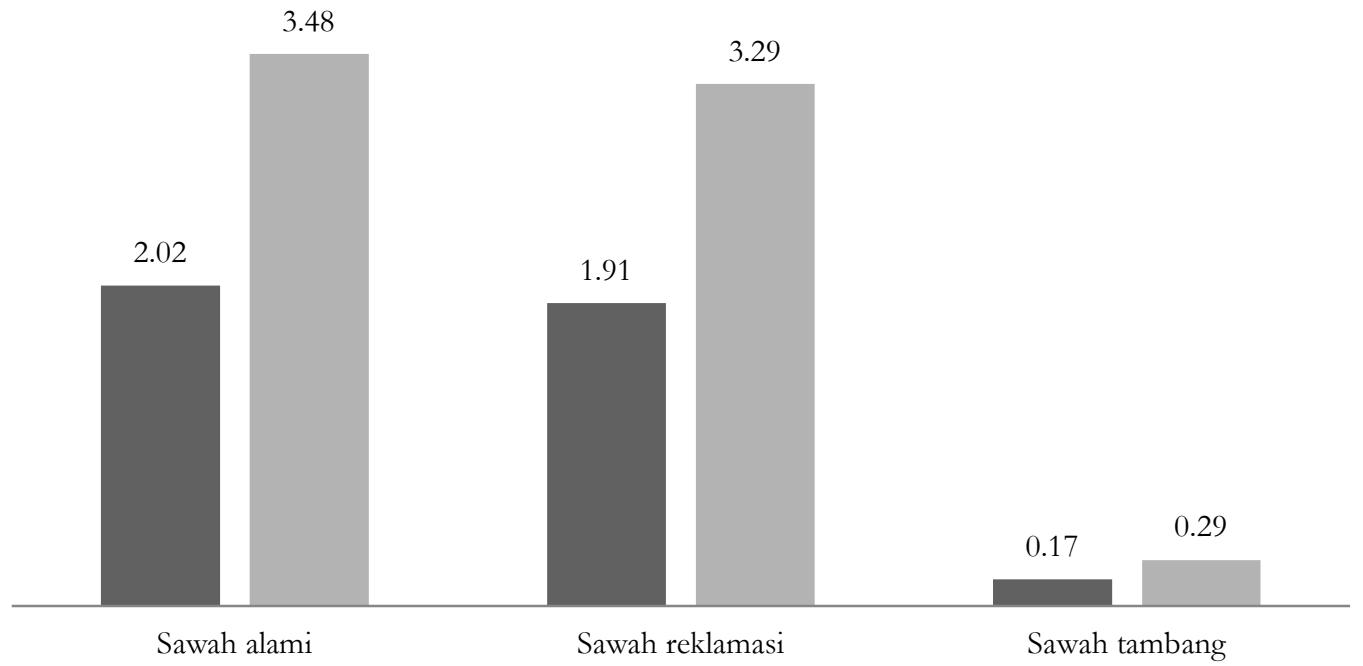

Gambar 6. C-organik dan bahan organik tanah.

\section{Kesimpulan}

Transformasi pada tanah sawah alami, sawah reklamasi dan sawah tambang dapat dilihat dari parameter fisika tanah dan kimia tanah yang dialami pada masing-masing proses pembentukan tanah tersebut. Secara sifat fisika tanah yang mempengaruhi tranformasi karakteritik tanah bekas penambangan emas ini adalah tekstur tanah yang berkaitan dengan pembentukan lapisan tapak bajak yang membantu penggenangan sawah dan perakaran tanaman untuk proses pertumbuhan dan produktivitas tanaman padi, bobot volume tanah dan berkaitan dengan total ruang pori tanah yang baik untuk pertumbuhan optimum tanaman padi. Sifat kimia yang mempengaruhi karakteristik tanah bekas penambangan emas juga dapat dilihat dari $\mathrm{pH}$ tanah yang relatif netral akibat proses penggenangan yang mampu menciptakan $\mathrm{pH}$ tanah yang stabil seperti tanah sawah alami dan diikuti oleh sawah reklamasi namun tidak menetralkan tanah tambang karena sisa proses penambangannya. Pengaruh sifat kimia tanah karbon organik yang berhubungan dengan suplai bahan organik yang diperoleh oleh sawah alami saat pasca produksi dan sawah reklamasi dari input bahan organik menunjukkan nilai sedang namun pada tanah tambang yang tidak memperoleh input bahan organik serta mengalami pengkisan lapisan atas tanah disaat proses penambangan memiliki kriteria karbon organik yang sangat rendah. 


\section{Jurnal Tanah dan Sumberdaya Lahan Vol 8 No 1: 179-188, 2021 e-ISSN:2549-9793, doi: 10.21776/ub.jts1.2021.008.1.21}

\section{Daftar Pustaka}

Ahyani, M. 2011. Pengaruh Kegiatan Penambangan Emas Terhadap Kondisi Kerusakan Tanah Pada Wilayah Pertambangan Rakyat di Bombana Provinsi Sulawesi Tenggara. Magister Ilmu L:ingkungan, Universitas Diponegoro.

Anderson, F. 2018. Konversi lahan pertanian menjadi lahan pertambangan terhadap lingkungan dengan GIS (Geographic Information System ) di Nagari Padang Sibusuk Kabupaten Sijunjung. Fakultas Pertanian, Universitas Andalas.

Arabia, T. 2009. Karakteristik Tanah Sawah pada Toposekuen berbahan Induk Volkanik di Daerah Bogor - Jakarta. Intitut Pertanian Bogor.

BPPP. 2004. Tanah Sawah dan Teknologi Pengelolaannya. Pusat Penelitian dan Pengembangan Tanah dan Agroklimat (Puslitbangtanak), 377.

BPS. 2020. Executive summary of paddy harvested area and production in Indonesia 2019. https://www.bps.go.id/publication/2020/07/1 0/32247632fa792a2f3f28a644/ringkasaneksekutif-luas-panen-dan-produksi-padi-diindonesia-2019.html.

BPT. 2009. Analisis Kimia Tanah, Tanaman, Air, dan Pupuk ( dan L. R. W. B.H.Prasetyo, Djoko Santoso (ed.); 2nd ed.). Balai Penelitian Tanah.

Burkhard, B., Müller, A., Müller, F., Grescho, V., Anh, Q., Arida, G., Bustamante, J. V. J., Van Chien, H., Heong, K. L., Escalada, M., Marquez, L., Thanh Truong, D., Villareal, S. B. and Settele, J. 2015. Land cover-based ecosystem service assessment of irrigated rice cropping systems in southeast Asia-An explorative study. Ecosystem Services 14: 76-87, doi: 10.1016/j.ecoser.2015.05.005.

Chivenge, P., Angeles, O., Hadi, B., Acuin, C., Connor, M., Stuart, A., Puskur, R. and JohnsonBeebout, S. 2020. Ecosystem services in paddy rice systems. In: The Role of Ecosystem Services in Sustainable Food Systems (Vol. 1). Elsevier Inc., doi:10.1016/b978-0-12-816436-5.00010-x.

Fuhrmann, I., Maarastawi, S., Neumann, J., Amelung, W., Frindte, K., Knief, C., Lehndorff, E., Wassmann, R. and Siemens, J. 2019. Preferential flow pathways in paddy rice soils as hot spots for nutrient cycling. Geoderma, 337: 594-606, doi: 10.1016/j.geoderma.2018.10.011.

Hardjowigeno, S. 2007. Ilmu Tanah. Jakarta: Akademika Pressindo. 296 Halaman.

Hardjowigeno, S. dan Rayes, M.L. 2005. Tanah Sawah Karakteristik, Kondisi dan Permasalahan Tanah Sawah di Indonesia. Bayumedia Publishing. Malang.
Hu, W., Tabley, F., Beare, M., Tregurtha, C., Gillespie, R., Qiu, W. and Gosden, P. 2018. Short-term dynamics of soil physical properties as affected by compaction and tillage in a silt loam soil. Vadose Zone Journal 17(1):180115, doi: 10.2136/vzj2018.06.0115.

Huang, L.M., Thompson, A., Zhang, G.L., Chen, L.M., Han, G Z. and Gong, Z.T. 2015. The use of chronosequences in studies of paddy soil evolution: A review. Geoderma, 237: 199-210, doi: 10.1016/j.geoderma.2014.09.007.

Janssen, M. and Lennartz, B. 2007. Horizontal and vertical water and solute fluxes in paddy rice fields. Soil and Tillage Research 94(1): 133-141. https://doi.org/10.1016/j.still.2006.07.010.

Jin, Z., Shah, T., Zhang, L., Liu, H., Peng, S. and Nie, L. 2020. Effect of straw returning on soil organic carbon in rice-wheat rotation system: A review. Food and Energy Security 9(2): 1-13, doi: 10.1002/fes3.200.

Kölbl, A., Schad, P., Jahn, R., Amelung, W., Bannert, A., Cao, Z. H., Fiedler, S., Kalbitz, K., Lehndorff, E., Müller-Niggemann, C., Schloter, M., Schwark, L., Vogelsang, V., Wissing, L. and Kögel-Knabner, I. (2014). Accelerated soil formation due to paddy management on marshlands (Zhejiang Province, China). Geoderma, 228-229, 67-89, doi: 10.1016/j.geoderma.2013.09.005.

Krik, G. 2004. The biogeochemistry of submerged soils. Wiley, Chichester.

Kukal, S.S. and Sidhu, A.S. 2004. Percolation losses of water in relation to pre-puddling tillage and puddling intensity in a puddled sandy loam rice (Oryza sativa L.) field. Soil and Tillage Research 78(1): 1-8, doi: 10.1016/j.still.2003.12.010.

Kurnia, U., Agus, F., Adimihardja, A. dan Dariah, A. 2006. Buku Petunjuk Teknis Analisa Fisika Tanah. Buku Petunjuk Teknis Analisa Fisika Tanah, Analisa Fisika Tanah, 1-261.

Liu, C.-W., Yu, W.-S., Chen, W.-T. and Chen, S.K. 2005. Laboratory investigation of plough sole reformation in a simulated paddy field. Journal of Irrigation and Drainage Engineering 131(5): 466-473, doi: 10.1061/(asce)07339437(2005)131:5(466).

Qiao, J., Zhu, Y., Jia, X., Huang, L. and Shao, M. 2018. Estimating the spatial relationships between soil hydraulic properties and soil physical properties in the critical zone $(0-100 \mathrm{~m})$ on the Loess Plateau, China: A state-space modeling approach. Catena 160: 385-393, doi: 10.1016/j.catena.2017.10.006.

Rahayu, A., Utami, S.R. dan Rayes, M.L. 2014. Karakteristik dan klasifikasi tanah pada lahan kering dan lahan yang disawahkan di Kecamatan 
Jurnal Tanah dan Sumberdaya Lahan Vol 8 No 1: 179-188, 2021

e-ISSN:2549-9793, doi: 10.21776/ub.jts1.2021.008.1.21

Perak Kabupaten Jombang. Jurnal Tanah dan Sumberdaya Lahan 1(2): 79-87.

Witt, C. 2005. Paddy soils. Elsevier Ltd.All Rights Reserved, 10.

Yi, J., Qiu, W., Hu, W., Zhang, H., Liu, M., Zhang, D. and $\mathrm{Wu}$, T. 2020. Effects of cultivation history in paddy rice on vertical water fl ows and related soil properties. Soil \& Tillage Research 200 : 104613, doi: 10.1016/j.still.2020.104613.
Yudhistira, Y., Hidayat, W.K. dan Hadiyarto, A. 2012. Kajian dampak kerusakan lingkungan akibat kegiatan penambangan pasir di Desa Keningar daerah kawasan Gunung Merapi. Jurnal Ilmu Lingkungan 9(2): 76, doi: 10.14710/jil.9.2.76-84. 